\title{
Apartheid, clinical psychology, and breaking barriers ${ }^{1}$
}

Accepting an invitation to review the book Apartheid and the making of a Black psychologist was an easy decision despite competing demands and deadlines. It was, after all, a memoir by Chabani Manganyi. As a student, I had great admiration for Manganyi, because he represented hope for aspiring psychologists of colour in a country marked by fervent attempts to suppress Black advancement. My earliest recollection of this icon of South African Psychology relates to his book Being-black-in-the-world (1973), which not only got many hooked on his writing and urged a following of his work, but it provoked a critical engagement with issues of race and the social and political forces that affected the lives of the majority of South Africans. That he published the work at a time when not many were raising these issues in the literature earned him enormous respect.

Given his experiences in the deepest and darkest days of apartheid, Manganyi has much to impart about the rocky road that Psychology traversed in South Africa, and he was at the forefront of Clinical Psychology's march to freedom, perhaps without even realising it at the time. For younger members of the discipline it would be of interest to know that he was the first person of colour to gain registration as a clinical psychologist in apartheid South Africa. Notwithstanding the numerous accolades, Manganyi remains a modest and unassuming man, contributing immensely to the discipline and wider society while preferring to avoid the limelight in which he could so easily have basked.
Anthony L Pillay

Department of

Behavioural Medicine

University of

KwaZulu-Natal

Durban

Fort Napier Hospital

Pietermaritzburg 
A memoir can reflect simply a chronicling of the life of an individual that includes some boring and rather ordinary parts, but Manganyi has carefully selected those aspects of his life and experience that he believed the reader will find interesting. Either that, or there is little ordinary about his life. As a result, the collection presents nothing that the average reader will not find captivating. Despite having been familiar with some of Manganyi's experiences, every chapter and experience described proved fascinating. The book is written in a clear and uncomplicated style that makes it easy to read and follow. The author provides vivid portrayals of people, places and events, with his own thoughts and emotions, and those of his subjects, poignantly described to keep the reader's experience as real as possible.

Manganyi covers a few broad thematic areas in the book, including his training as a clinical psychologist, his career and work experiences, his entry into and experiences in the field of life writing, and his meaningful foray into forensic psychology. The book opens with his early life in rural Limpopo and the reader is given brief glimpses of Manganyi as a child, his love for his mother and his gratitude for his parents' insistence that he complete his schooling. His account of his father's marriage to a second wife "like so many African men in those days" grounds the reader in the destructive nature of apartheid on family life, when the migrant labour system deprived children of fathers and women of husbands. Although he had supportive parents Manganyi's early years were characterised by the hardships of rural South Africa, but his resilience becomes evident quite early.

Although Manganyi had previously written on the tribulations surrounding his clinical psychology training, he brings additional insights here. It is imperative that Psychology trainees read this book to gain an understanding of the discipline's history and how far we have come. His request to be trained posed a quandary to the authorities because, as he articulated in an earlier publication, "it was as if Africans were not expected to train as clinical psychologists!" (Manganyi, 2013: 280). The placement he received in a neurosurgery and neurology department at Baragwanath hospital (rather than a mental health unit), the lack of a clearly defined training programme and the unconventional internship, all convey the substantive challenges, and the steely determination of the man. A sad indictment of the system was that this Psychology intern learned of Luria's work from speech and hearing therapy colleagues, rather than psychology supervisors. Despite the hurdles, Manganyi published a research paper on hysteria in the South African Medical Journal while still an intern! Perhaps to remind him of his place and entrench apartheid control, the editors changed the article title, without consultation, replacing the word "African" with the derogatory "Bantu".

In characteristic Manganyi style he relates his experiences under the oppressive apartheid system and the forces denying him a "normal" clinical psychology 
internship; but while the reader may expect (or want) to hear angry words and retaliations, these are not forthcoming. This is despite his recollection at one point that he was "a very angry man" which is contextualised within the period of his living abroad while his country was in turmoil. Perhaps reminiscent of another great South African, Manganyi appears to have the power to reconcile with these adversities more easily than many of us. Throughout the book, there is a gentleness about the way he conveys even the most difficult and challenging experiences. Having had the good fortune to spend a memorable afternoon in his company, it is easy to attest to the calmness of the man.

The author provides an informative account of his subsequent education in the United States, especially his interactions with academics at some of the Ivy League universities. While not directly stated, the comparative responsiveness of academics across the Atlantic is quite glaring. Evident also is the extent to which he found the US training supplementing his unconventional clinical psychology training, especially in psychoanalytic psychotherapy. He noted that "there could have been no better remedy for the deficiencies of my race-based training at home than a postdoctoral fellowship at Yale." As was not uncommon for Black travellers at the time, Manganyi struggled to get his passport renewed in time for the journey, and he acknowledges the assistance of anti-apartheid struggle icon Beyers Naude, among others, who came to his aid.

Towards the end of his period (mid-1970s) at Yale, Manganyi became concerned about the political violence at home and felt the need to do something to help affected communities on his return. To this end he established the Political Violence and Health Resources Project for which he obtained US funding to conduct research and provide services to those affected. There are interesting, and perhaps unexpected, descriptions of tensions with other groups doing similar work.

The fact that Manganyi is widely read and influenced by many great writers, theorists and philosophers comes through. The influence of Victor Frankl on his thinking and way of looking at the world and the self, introduces his account of the next phase in his career, namely psychobiography or life writing. While one may ponder the connection between the author's psychology career and life writing, he points out that "Psychotherapy is a privileged witnessing of the intimate lives of others and, on a different plain, so is biography". As seen later in the book when he details his forensic psychology approach, his skills in these two areas marry well, to provide an ideal platform to formulate explanations of accused persons' behaviour and thinking while rooting these in the individuals' life history, much like a psychodynamic formulation - but without the jargon. It becomes clear that the life writing work was one of Manganyi's greatest passions, and 
one might even venture to postulate that it was probably what he enjoyed most in his lengthy and vibrant career. Despite his psychobiographies being highly acclaimed, he refers to them as "experiments".

The fascination with significant writers and artists such as Es'kia Mphahlele, Gerard Sekoto and Dumile Feni, among others, led to a notable part of Manganyi's literary works. A most enjoyable section of the memoir is the beautifully described meetings with Sekoto in Paris, the travels and challenges encountered in locating and interviewing him, not least of which was Sekoto's tendency to be "long-winded". Much like a scene from a movie, the description of Sekoto opening a brown suitcase revealing a previously unseen "treasure trove of drawings" is vividly captured. What follows continues the analogy with Manganyi offering to take the drawings back to South Africa, despite knowing the risks to his own safety, believing it to be the only way to have them professionally copied and documented. Manganyi's humanity and generosity comes though strongly here, as what follows is a series of interesting developments, both in South Africa and with Sekoto in Paris.

One of the larger sections of the book is devoted to the author's, perhaps unexpected, involvement in forensic psychology. Two interesting and incisive chapters address his work in apartheid era court cases, mainly of a political nature. His expertise was sought from many defence teams, and included high profile cases such as those of Robert McBride and Peter Mokaba. Considering the ruthless apartheid machinery, and that forensic psychology was in its infancy, one has to respect Manganyi's courage and willingness to enter these contests where the odds were stacked against the defence team and especially its Black expert witness. Characteristically, the author reports rather modestly on his forensic work while acknowledging the heaviness he felt knowing the death penalty was a sentencing option.

Manganyi painstakingly describes his own thoughts and feelings while working on the cases, revealing his dedication and commitment to his craft and to the socio-political cause. His worries about the extent to which his reports and testimony would help those on trial comes through, and again reveals the commitment and compassion that distinguishes him from some modern day forensic psychology professionals. The section on the McBride trial is well written and informative, providing a carefully crafted description of Manganyi's approach to the task and the psychosocial profile of the accused, contextualising his political leanings within his familial and socio-political environment. In a chapter on crowd behaviour the reader can feel his agonizing quest to learn more about the phenomenon so as to be able to provide the court with the best possible, scientifically-based, explanation for the accused's behaviour within a group setting. His approach to the work is consistent with the development of his career, 
namely that of extensive reading and learning - a significant lesson for students and young professionals.

Manganyi's tenure as Professor and Head of Psychology at the Umtata campus of the University of Fort Hare (later renamed University of Transkei), relates perhaps one of the few parts of the book where he reflects his disappointment in a work context that he entered with great optimism, but which was not to be. Once again, the apartheid tacticians had worked against him (and other progressives) by ensuring control of all state structures, including the conniving homeland policy and the puppets installed to run the "homelands". After an initial period of exciting developments, the author reflects dejectedly on the deteriorating conditions including, inter alia, the Transkei security force abductions and torture of students, and his unwillingness to continue in that environment.

The book ends with a chapter on Manganyi's move to higher education administration, as Vice-Chancellor of the then University of the North. Especially touching are the descriptions of the challenges faced and the role and effectiveness of then Chancellor Nelson Mandela in dealing decisively with apartheid bureaucrats. Mandela's confidence in Manganyi is evident even at the end of his tenure when he requested him to nominate his replacement.

The book is a "must read" for anyone who has a desire to know Psychology's history in South Africa, revealing an extraordinary story of determination and achievement in the face of adversity. Manganyi's memoir presents a riveting journey from humble beginnings to receiving accolades from a global icon.

\section{References}

Manganyi, N C (1973) Being-black-in-the-world. Johannesburg: Spro-cas / Ravan. Manganyi, N C (2013) On becoming a psychologist in apartheid South Africa.

South African Journal of Psychology, 43, 278-288. 